Journal of

Public Policy and Administration (JPPA)

\title{
EFFICIENT PUBLIC FINANCIAL MANAGEMENT FOR EFFECTIVE GOVERNANCE AND SUSTAINABLE URBAN DEVELOPMENT
}

Salome Musau 


\title{
EFFICIENT PUBLIC FINANCIAL MANAGEMENT FOR EFFECTIVE GOVERNANCE AND SUSTAINABLE URBAN DEVELOPMENT
}

\author{
${ }^{1}$ Salome Musau \\ Department of Accounting and Finance, Kenyatta University, PO BOX 43844-00100, Nairobi, \\ Kenya. \\ Email: musau.salome@ku.ac.ke
}

\begin{abstract}
Purpose: This paper looked at the principles of good financial governance that including: Financial planning practices, Revenue mobilization strategies, monitoring and evaluation units and assessed how they affect sustainable urban development.

Methodology: Through a situational analysis, this report comes up with a conceptual literature which evaluates existence of correlation between efficient governance, monetary management as well as sustainable urban development.

Findings: The paper established that the fundamental reason for public financial management is logical, efficient and time-time evaluation of financial practices employed by the urban councils to promote institutional learning on one hand as well as improving future performance and therefore, enhance the standard of their financial decision making. And thus, it concludes that effective and efficient use of public funds depends on the level of Accountability. Also, good financial governance and good institutional structures are crucial in attaining sustainable development.
\end{abstract}

Unique Contribution to Theory, Practice and Policy: The paper recommends that, public institutions should strive to attain good financial governance which enhances management decisions, accountability and organization learning in attaining sustainable development. This paper also recommends that M\&E should support evidence-based decision making as well as nominal compliance. In order to enhance planning, service delivery and policy process $M \& E$ should be properly institutionalized, funded and located.

Key words: Financial Governance, Public Finance Management, Sustainable Development 
Journal of Public Policy and Administration

ISSN 2520-5315 (Online)

Vol 6, Issue 1, No.1, pp 21 - 30, 2022

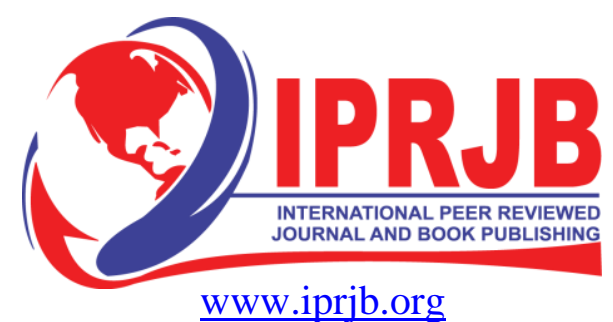

\section{0: INTRODUCTION}

Good monetary governance has been observed as a powerful contributor to effective and efficient resource use, sound fiscal management, whose results culminate in accountability and transparency (African financial governance status report, 2011). So as to be able to achieve policy objective and at the same time deliver public services efficiently it is vital to manage public resources properly. World bank report, 2008 alluded to the fact that, although effective and efficient public resource utilization is a concern that is common at all levels of government, the proper utilization of delocalized public holdings at the county government level is a unique contention point. This is notably right in under developed countries as well as where central monetary management appear to be some advantage in comparison to local systems of managing finances (UNhabitant, 1998).Most LDCs nations have lagged behind in terms of developments. This is largely attributed to the challenges of Public Finance Management and Governance. Sustainable development is as a result of good Public Finance Management and Governance, a pillar upon which many developed states have capitalized on successfully.

Sound systems of governing finances are crucial for purpose of creating the highest level of accountability and transparency in organizations finances, increase the better resource utilization as well as ensuring long-term economic success and sustainable development. Efficient management of public finances is key a key enabler in public sector to achieve its policy objectives as well as efficiently deliver public services. Sustainable development is as a result of good Public Finance Management and Governance, a pillar upon which many developed states have capitalized on successfully. Weak financial management practices as well as poorly designed intergovernmental fiscal systems would make locally generated finances at risk of either being "captured" then channeled far from there purposed use by local politician or being improperly changed by central or local government officers prior to reaching the common people.

For the devolved government units, there is need to make sure that public resources are properly managed as this is critical for efficient and effective delivery of public services. With critics of devolution quick to indicate that decentralized governments have weak administrative structures, effective local financial management can go a long way in negating the potential criticisms aimed at decentralization. According to Hitss et al., (2011), there are several factors that influence sound management of local finances both in transition as well as developing economies. Shah, (2007) adds that if local financial management practices are weak, there is a high likelihood that local government finances are diverted away from the intended use by local government officials who act as custodians on behalf of the public in accordance with agency theory.

\subsection{PUBLIC FINANCIAL MANAGEMENT}

Monetary management is a key activity in the municipality or socio-economic enhancement of a country. Managing public sectors finance properly is a pre-condition for economic development, better public service delivery as well as cornerstone of good governance. Still, even with 
Journal of Public Policy and Administration

ISSN 2520-5315 (Online)

Vol 6, Issue 1, No.1, pp 21 - 30, 2022

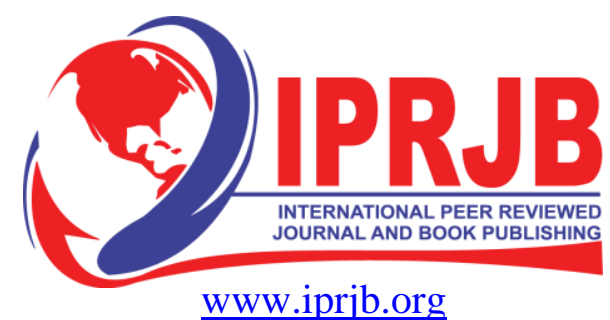

noticeable attempts by multinational financial institution and growth agencies to enhance public monetary management in underdeveloped as well as developing countries around the globe, such coming up with a budget process which is more inclusive as well as transparent, by coming up with a result based budget planning as well as by introduction of financial management systems which are integrated, apparently there is little idea on the milestone to which third world countries economically divide they public funds based on correspondence with their established policy priorities. In addition, almost none is known in majority of the countries on the political efficiency in the decision-making process where budget allocations are made (Fiador, 2013).

According to Bird (2010), effective funds generation strategies for units of the government are an important pre-condition for the well-being delivery of service to the public. This is because, other than generating funds, internal finance mobilization has the ability to foster administrative as well as political accountability by empowering communities (Oates, 2011). As per Baumann (2013) sound delocalization requires to provide resources as well as scope for the contribution to development by all stakeholders. The provision of public services by local governments needs adequate monetary holdings and thus making fund collection very crucial among the units decentralized of government for instance county governments in Kenya (Gituma, 2017).

While affirming the need of fund collection in the decentralized units Scott (2016) was of the opinion that in addition to revenue collection, localized revenue mobilization is required to have the prerequisite potential of fostering administrative as well as political accountability and transparency thereby enabling devolved government units with the capacity to empower the communities. Successful decentralization of government financial functions therefore needs to provide scope as well as holdings to the promotion to development by all stakeholders while the delocalized governments acting as a layer of government necessitating whose effective delivery of services is dependent upon adequate financing (Gituma, 2017).

To raise revenue for local devolved government units, fees and taxes are mobilized through the national government and then ploughed back to the decentralized units (Fjeldstad, Chambas\& Brun, 2014). For example, in Malawi passport fees which is a non-tax revenue are mobilized via the national government and then redirected to county governments. In some other cases collection of revenue is sourced from outside by a collection of distinguished agents in the decentralized governments (Mrutu\&Mganga, 2016). According to Fjeldstad and Semboja (2000), a commonly found characteristic in decentralized local revenue collection activities is the large count of revenue tools used by devolved governments. Local councils seem to collect whatever fees, charges as well as taxes they can. Local governments also receive funds through external transfers from regional or central government level, mostly in the form of mandatory revenue sharing arrangement as well as grants (Bahl \& Smoke 2003).

Budgeting ensures resources are send to spending units to enable them implement their expenditure programs (Lee, 2012). Budgets are key policy documents that outline the local government's fiscal priorities and guide future transactions and operations. However, budgets have to do more than meet fiscal or even legislative obligations. Since decisions about frequently used services such as transportation, community recreation as well as collection of garbage are made in urban government budgets, they should also reflect the needs of the community as well 
Journal of Public Policy and Administration

ISSN 2520-5315 (Online)

Vol 6, Issue 1, No.1, pp 21 - 30, 2022

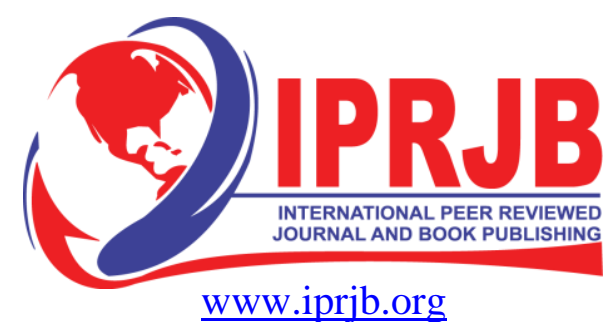

as the goals of the urban councils. In order to achieve this, the budgeting process should give an effective criterion of estimating as well as evaluating spending pressures relative to the taxable capacity of the local economy (Fan, 2015).Sound monitoring and oversight are key to effective PFM reforms as well as effective governance. There is need to clear rules on transparency and reporting for a well-functioning PFM system as well as enforceable sanctions for failure. Internal oversight comprises of the internal audit function which must be sound and should be as per the generally accepted auditing standards in accordance to planning, staffing as well as reporting.

A monitoring and evaluation substructure is a device to check whether anticipated objectives of the public finances are attained. It is construed as a means to study from experiences to enhance delivery of services in urban centers, divide resources more efficiently as well as demonstrating results as part of accountability to crucial stakeholders (World Bank, 2004). From existing research, in urban planning the $\mathrm{M} \& \mathrm{E}$ system is taken as a key management tool that has great potential to aid in many planning practices. There must be public participation as well as technical quality in the project for a well-designed $M \& E$ system to improve performance of the projects. The skills cost as well as time needed for every M\&E tool should be considered to improve the process of the system.

The definition of public sector M\&E is derived from the belief that M\&E supports accountability function and goes hand in hand with auditing field, compliance as well as performance management. This indicates that, $M \& E$ for accountability is in the form of public oversight which appears when public hold government responsible for the expenditure of finances as well as performance on programs thus playing an oversight role. High levels of scrutiny are anticipated in accountability-oriented $\mathrm{M} \& \mathrm{E}$ as well as judgment usually done against set standards and norms which have been set for a range of performance areas. It comprises the effective management of personnel, budgets legal and regulatory compliance with procedures and processes any change from any of the set standards welcomes censure. Accountability based $M \& E$ is viewed as a supporting governance unit which comprises the whole management, cultures of the institution as well as operating systems.

\subsection{EFFICIENT FINANCIAL GOVERNANCE}

The idea of good governance has largely been used in setting up development programs at its valuable undertaking a comprehensive analysis to get to know its importance which emerges from the historical context where many governments were faced with development and legitimacy crisis because of bad governance. As per Motubatse,Ngwakwe and Sebola (2017),sound public sector governance leads to sound making of decisions and better resource utilization and thus steering accountable the management of those holdings. Sound administration can be featured by deeper analysis, that gives key pressures for enhancing performance of public institutions as well as handling corruption.

According to Lamdany \& Martinez-Diaz (2009), the answer for sound governance has been researched by multinational organs such as IMF and question of transparency has been evaluated. Ojok and Basheka(2016) clarify the idea of governance by citing four elements, comprising of predictability, participation, accountability as well as transparency. Based On the 
Journal of Public Policy and Administration

ISSN 2520-5315 (Online)

Vol 6, Issue 1, No.1, pp 21 - 30, 2022

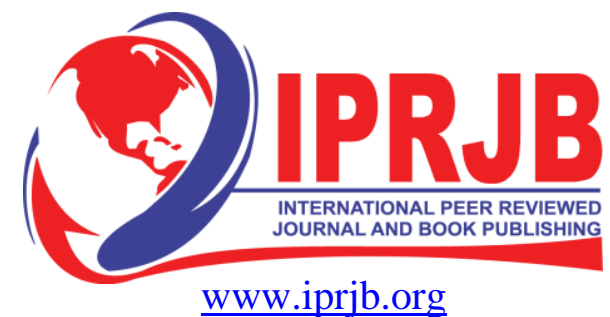

same note, Abd-Aziz, Rahman, Alam and Said(2015) argue that good governance in the public sector is achieved when the following 9 characteristics are considered: strategic vision, involvement, effectiveness and efficiency, consensus orientation, transparency, responsiveness, equity building, accountability as well as rule of law.Based on the best practices in governance and finance, the UK department of for social development (2005) intimates that governance is about ensuring that things are done and not about doing. The major elements of governance as outlined by Office of the Scottish Charity Regulator (OSCR) are as shown in figure 1. The elements of good governance are many and have been portrayed in a variety of ways
by practitioners and scholars of good governance. The following diagram that tries to
summarise these elements of good governance has been adopted from a publication of the
Office of the Scottish Charity Regulator (OSCR).

Good Financial Management: Planning

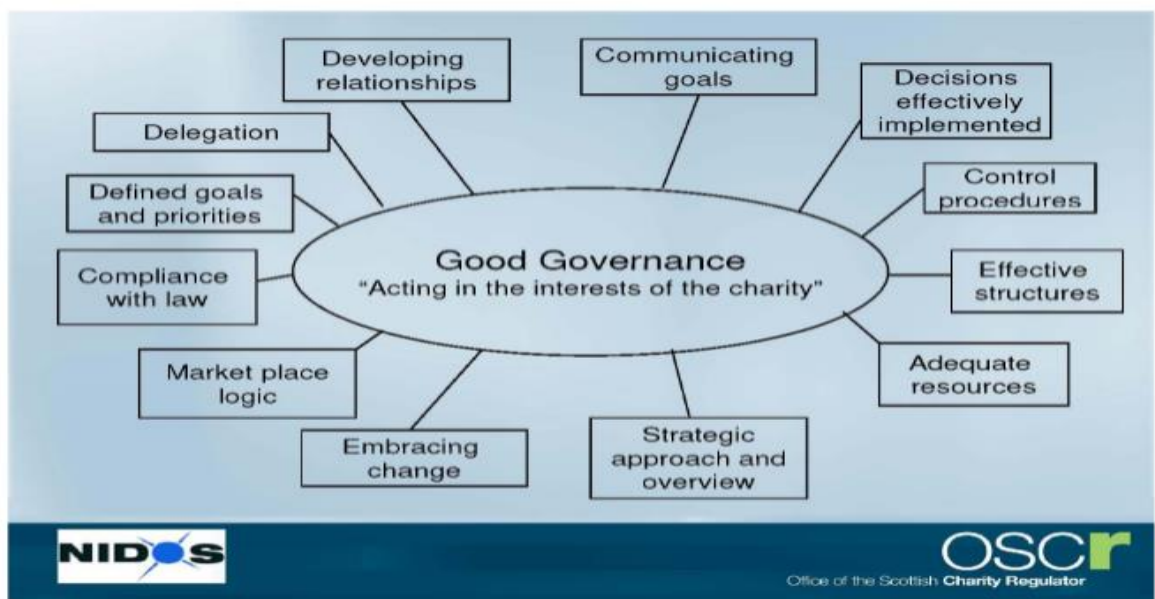

The Office of the Scottish Charity Regulator (OSCR) (n.d.) also outline the major elements of good financial governance as; vision and strategy, risk strategy, scheme of delegation/segregation of duties, robust internal controls, accurate, timely and relevant

Based on the preceding study, a conceptual literature for public financial management as well as urban sustainable development was proposed to show the interconnection between urban sustainable development as well as public monetary management which is applicable in most urban settings. The framework holds that public financial management as indicated by revenue mobilization practices; financial planning and effectiveness of M\&E have a role to play towards sustainable development of urban centers in Kenya. This relationship was hypothesized to be moderated by public governance as shown in figure 2 . 


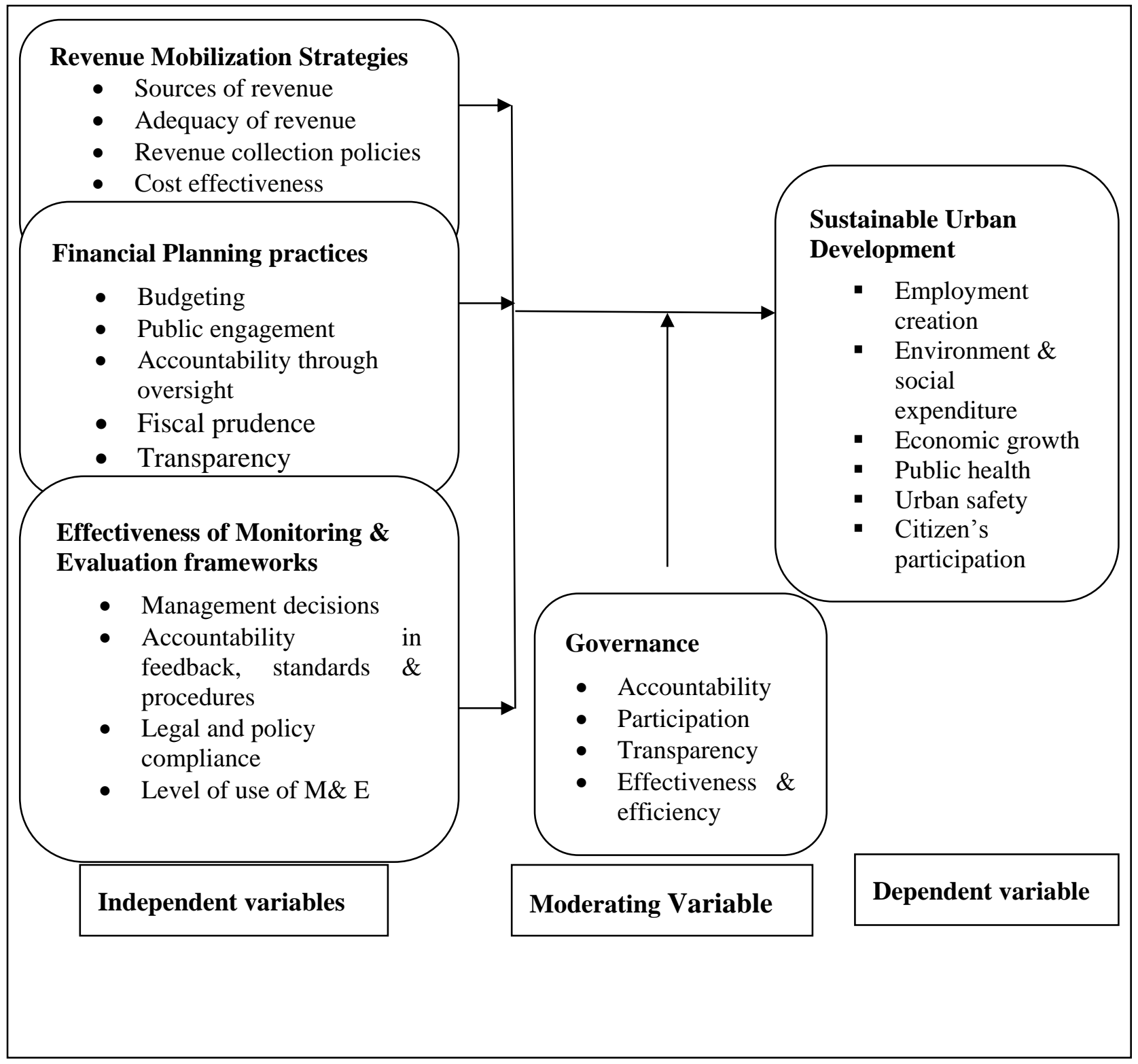

Figure 2: Conceptual Framework

\subsection{METHODOLOGY}

The assumption of the paper is that revenues generated by urban councils are inadequate while the elasticity of the revenue bases and diversity is limited. This paper looked at the principles of good financial governance that including: Financial planning practices, Revenue mobilization strategies, effectiveness of Monitoring and Evaluation units and assessed how they are followed 
Journal of Public Policy and Administration

ISSN 2520-5315 (Online)

Vol 6, Issue 1, No.1, pp 21 - 30, 2022

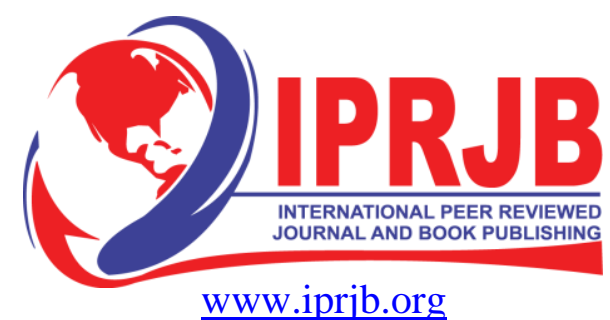

by urban councils. In addition, it also looked at the moderation role played by good governance in the relationship between public financial management practices and sustainable urban development. Through a situational analysis, this discussion developed a conceptual framework that evaluates the correlation between efficient monetary governance as well as sustainable urban development.

\subsection{FINDINGS}

This paper took into consideration the considerable opinion, the literature as well as reconstruction of public financial management practices in different jurisdictions. This paper established that effective revenue collection practices have a notable influence on urban sustainable development. The research also established that devolved government units have various sources of revenue, but some of them are inefficient in mobilizing the funds which translates to the worse level of delivery of services. Devolved government units have formulated policies as well as laid the procedures guiding revenue mobilization process, even if these policies and guidelines are not always adhered to. With regard to adequacy of the resources mobilized, this paper found that despite commendable improvement in revenue mobilization by local government units, revenues generated are not adequate to facilitate effective delivery of services as the process is regularly hampered by corruption as well as inefficiencies. Choosing poor means of revenue collection has therefore adversely affected provision of requisite services.

It established that Budget forecasts are key devices of fund management brought about to direct and control the businesses of multifarious and large institutions. Expansion of the legislature's role in budgeting is a new emerging issue to budgetary approaches. With legislative budgeting, new responsibilities must be contained both to longstanding appropriation processes, as well as to political relations with government. Shah, (2009) Kung et al (2013). Fiscal decentralization and diversification equip sub-national governments to collect enough revenue from local sources thereby minimizing their dependence on the national government Noore, et al (2012). Public engagement, accountability through oversight, fiscal prudence, and transparency through thirdparty intermediation were identified as fundamental components of a healthy budget process. By building a budget process around these four components, different stakeholders can collaborate to better identify and analyze relevant economic and social factors that shape the capacity of urban budgets.

Proper and independent, objective assurance and consulting oversight adds worth and enhance a firm's businesses. It aids an entity achieve own goals through coming up with logical, organized way to improve as well as evaluate the soundness management of risks, control processes as well as governance Wanjara, (2015). At all times people working for entities as well as governing bodies should observe the public interest when performing duties, in correspondence with policies of the government as well legislation requirement, keeping off from individual interests, where necessary, perform opposite to presumed interest of the organization so as to ensure public sector get better governance. Participating in the interest of the public means a more benefit to society, which should result in positive results for service consumers and other stakeholders(IFAC, 2015) 
Journal of Public Policy and Administration

ISSN 2520-5315 (Online)

Vol 6, Issue 1, No.1, pp 21 - 30, 2022

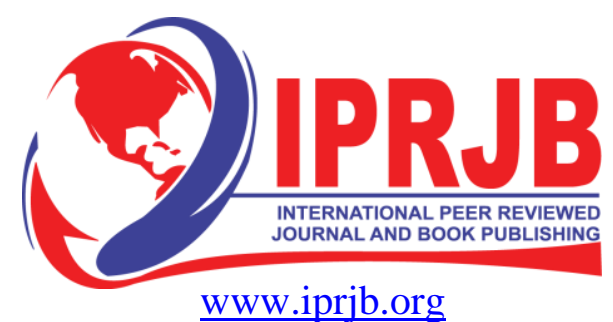

\subsection{CONCLUSIONS}

The paper concludes that the fundamental reason for public financial management is logical, efficient as well as time-time evaluation of financial practices employed by the urban councils to enhance future performance as well as promoting institutional learning and therefore, improve the standard of their financial decision formulation. The study thus concludes that effective revenue mobilization practices positively and significantly influence urban sustainable development through provision of quality services to the public. The study also concludes that though devolved government units have various sources of revenue, some of them are poor in mobilizing the revenues which translates to the adverse level of service delivery. Devolved government units also have formulated procedures guiding revenue mobilization process, but these policies are not always adhered to. Moreover, despite commendable improvement in revenue mobilization by local government units, revenues generated are still inadequate to facilitate effective delivery of services as the process is regularly hampered by inefficiencies as well as corruption.

With regard to urban financial planning, it was established that budgets are keyt tools of monetary management employed as they control and directs the running of large and multifarious institutions. With legislative budgeting, new roles must be contained both to longstanding appropriation processes as well as political relations with government. The paper also established that accountability through oversight, public engagement, transparency through third-party intermediation and fiscal prudence play a fundamental role in formulating a proper budget process. In this regard, a budget process based around accountability through oversight, public engagement, transparency through third-party intermediation and fiscal prudence fosters collaboration among various stakeholders in identifying and analyzing relevant economic and social factors shaping urban budgets capacity. Effective and efficient use of public funds depends on the level of Accountability. Also, good financial governance and good institutional structures are crucial in attaining sustainable development. Good governance enhances management decisions, accountability, organization learning as well as promoted good governance.

\subsection{POLICY RECOMMENDATIONS}

The paper recommends that, Institutions to strive to maintain sound and effective management of public resources as well as complete implementation of wide reforms in public sector. Firstly, there is need to strengthen as well as audit automation and updated techniques for better revenue collection and provision of services. In some revenue areas, outsourcing revenue collection may also improve the efficiency of the whole process. There is also need for devolved urban councils to improve the capacity of revenue staff so that they can appropriately make use of innovations and updated technologies to monitor as well as supervise revenue mobilization as well as use. There is also need lobby for legislative reforms to widen the revenue bases of devolved urban councils such as pushing for bond financing in the local credit market.

The study also recommends urban councils to adopt sound budgeting for better planning and controlling of limited finances in the achievement of whole as they are vital in directing and controlling financial management of public institutions. While preparing urban budgets, there is 
need to factor in accountability through oversight, public engagement, transparency through third-party intermediation and fiscal prudence play a fundamental role in formulating a healthy budget process.

Strengthening the controls within the organization as devices for evaluating and monitoring resources as well as ensuring maximum use. It is necessary to inform other partners what is happening. A platform should be provided to citizen so as to exercise their rights as well as to monitor the implementation of projects. This should be done through sensitization at the community level as well as civic education. This paper also recommends that M\&E should support evidence-based decision making as well as nominal compliance. In order to enhance planning, service delivery and policy process M\&E should be properly institutionalized, funded and located.

\section{REFERENCES}

Abd Aziz, M. A., Ab Rahman, H., Alam, M. M., \& Said, J. (2015). Enhancement of the accountability of public sectors through integrity system, internal control system and leadership practices: A review study. Procedia Economics and Finance, 28, 163-169.

Baumann, P. (2013). Sustainable livelihoods and political capital: Arguments and evidence from decentralization and natural resource management in India. London: Overseas Development Institute.

Fan, Y. (2015). The centre decides and the local pays: Mandates and politics in local government financial management in China. Local Government Studies, 41(4), 516-533.

Fiador. V, (2013). Determinants of Financial Governance Practices-Evidence from NGOs in Ghana. International Journal of Sociology and Social Policy, Emerald Vol. 33 Issue 1/2.. Availablefrom:

https://www.researchgate.net/publication/236842217_Determinants_of_Financial_Gover nance Practices-

Evidence_from_NGOs_in_Ghana_International_Journal_of_Sociology_and_Social_Poli cy_Emerald_Vol_33_Issue_12 [accessed Jun 11 2021].

Gituma, H. K. (2017). Determinants of effective revenue collection by Embu County, Kenya (Doctoral dissertation, University of Embu).

Kung, F., Huang, C., \& Cheng, C. (2013). An Examination of the Relationships among Budget Emphasis, Budget Planning Models and Performance. Management Decision, 51, 120140

Lamdany, R., \& Martinez-Diaz, L. (2009). Studies of IMF governance: a compendium. International Monetary Fund.

Motubatse, K. N., Ngwakwe, C. C., \&Sebola, M. P. (2017). The effect of governance on clean audits in South African municipalities. African Journal of Public Affairs, 9(5), 90-102. 
Noore Alam, S., Dian Nastiti, and Nur Ana Sejati (2012). Regional Autonomy and Local Resource Mobilization in Eastern Indonesia: Problems and Pitfalls of Fiscal Decentralization. Asian Affairs: An American Review Vol. 39, Issue. 1, 2012

Oates, L. R. (2011). Fiscal decentralization and intergovernmental fiscal relations: a crosscountry analysis. World Development, 28(2), 365 - 380.

Ojok, J., \&Basheka, B. C. (2016). Measuring the effective role of public sector monitoring and evaluation in promoting good governance in Uganda: Implications from the Ministry of Local Government. Africa's Public Service Delivery \& Performance Review, 4(3), 410439.

Scott, G. K. (2016). Influence of Revenue Mobilization Practices on Service Delivery in Decentralized Governments: The Case of District Assemblies in Ghana.

Shah, A. (2009). Budgeting and budgetary institutions. World Bank Publications

Wanjara, S. (2015). Influence of Internal Control System on the Financial Performance of Kenya Power. KCA University

World Bank, (2004). Public financial management in World Bank operations: a strengthened approach to enhance development and fiduciary objectives. World Bank 